Melanie Hien

\title{
Hungary and its civil society organisations - a fateful example for south-east Europe?
}

\begin{abstract}
Over the course of the last decade, the Hungarian government has been tightening the space for independent civil society. Fidesz, the ruling party, has been seeking to build long-lasting strings of national and right-wing power. Meanwhile similar tendencies are being practised in neighbouring countries, including Slovenia and Slovakia. The calculated protests of the European Union and its institutions are a reaction to Hungarian prime minister Viktor Orbán's open plans to establish an 'illiberal democracy' in Hungary and, if possible, in other parts of central and south-eastern Europe. Against this background, this article assesses the relationship between the Hungarian government and its civil society organisations on the one hand and the repercussions that this has for central and south-eastern Europe on the other. Three guiding questions must be discussed: why is civil society in Hungary in such a difficult position? Furthermore, in what ways are the structural discrimination against independent organisations being justified? And, finally, what is the role played by Hungary's east European neighbours?
\end{abstract}

Keywords: civil society, Hungary, Slovenia, Hungarian influence, foreign funding, democracy, Slovakia

\section{Introduction}

In the last two decades civil society ${ }^{1}$ in Hungary has gone through different developmental stages. The Hungarian government, under prime minister Viktor Orbán since 2010, has been engaged in tightening the space in which independent civil society operates as a means of building long-lasting strings of national and right-wing power. Furthermore, there are similar tendencies in place throughout neighbouring countries and across the Balkans, as the examples of Slovenia and Slovakia also show. In Slovakia, the Hungarian government is exercising influence via ethnic Hungarian organisations and cultural life; meanwhile, Slovenia's civil society landscape and its treatment by the government runs in clear parallel to Hungary's course of action and this is troubling. At official level, however, the concerns expressed by the European Union do not effectively target the Hungarian government and its allies, and sanctions or infringement proceedings are substantially ignored.

1 I assume that civil society is based on voluntary, self-generating, (largely) self-supporting, autonomous organisations. They are independent of the state and bound by a legal order or set of shared rules. Civil society is conceived to be an intermediate entity, standing between the private sphere and the state. This includes, inter alia, economic and cultural organisations, information and educational, developmental and civic associations (Diamond 1994: 5-7). 
This article assesses the state of the relationship between the right-wing Hungarian government and civil society organisations and the repercussions that this has for south-east Europe, namely the influence the Hungarian government is having on other countries in the region. To analyse the situations facing such countries, three guiding questions are important in terms of the direction this article takes: Why is civil society in Hungary in such a difficult position? How is the structural discrimination practised against independent organisations being justified? And, finally, what is the role being played by Hungary's east European neighbours?

The first part of this article - and its sub-sections - gives an overview of the civil society situation in Hungary, including the emergence of the so-called 'civic circles' which were founded in May 2002 following the defeat of the Fidesz government in the national parliamentary elections as a means of bringing the party back into office and preventing political apathy on the political right. It then seeks to capture the legislation on civil society legislation in Hungary, concerning specifically their financing and focusing on a new law on university foundations which is making lasting changes to the structure of higher education, before turning to highlight the public debate on civil society finances and the public media campaigns which are being waged against certain organisations. The second half of the article provides an overview of growing Hungarian influence in other countries throughout the region. This includes in Slovenian civil society, where there are similarities to the Hungarian treatment of organisations; followed by an examination of the civil society landscape in Slovakia, where the Hungarian government is active in providing funding to organisations. The article concludes with a summary of the theme and also provides some assessment of the potential motives for the actions of Fidesz and Orbán in this regard.

\section{Civil society in Hungary}

Hungarian civil society has significantly changed in terms of its political structures within the last two decades, from the emergence of Fidesz's 'civic circles' to the legislation on civil society organisations $(\mathrm{CSOs})^{2}$ and the recent changes to the structures of higher education. Additionally there have been public debates on the foreign funding of organisations alongside public media campaigns seeking to cast them in a bad light. The details of how this situation has evolved will be explained in each of the following sub-sections.

\section{Emergence of the so-called 'civic circles' and similar organisations}

When Fidesz lost the parliamentary elections in April 2002, departing prime minister and party leader Viktor Orbán told his supporters to form 'civic circles' - new social movements - throughout the country in order to bring the party back to office. In his view, Fidesz represented the nation and a role in opposition was thus not prop-

2 Following Diamond (1994), it is important to note that there is a difference between 'CSO' and 'NGO' in that the latter does not encompass all the organisations which belong to civil society. However, they have been used interchangeably in this article, not least when official documents do likewise. 
er to it. The newly-founded circles had to register with a democracy institute established by the party and, in further support of this new direction, new narratives such as the nation, family and religion - were drawn up to unite supporters with society. Activities for young people, such as camping, were established; the runes and the legends of the nomadic Hungarian tribes were shared with young people to educate them; and, to solidify the narratives, new stories were introduced around the founding myths of Hungary and King Stephen I. In May 2002, Orbán himself founded a circle which acted as a mediator between different groups. When Fidesz then evolved into a mass membership party, starting in the spring of 2003, some circles were able to be integrated into the party or its local branches which led to an increased number of party members (Greskovits 2020: 250-259).

In a speech in 2017, given to the Association of Christian Intellectuals, Orbán recalled the role of the circles in restoring Fidesz to power and as a response to the 'post communists' which had taken its place:

Together, we have developed the ability since 2002 to stand up to the returned anti-religious, anti-national and anti-family political leadership, while serving our country at the same time. ${ }^{3}$ (Magyar Kurír 2017)

He also referred to the activities organised in common with the circles and that they were the reason why the party had gained a two-thirds majority in the parliamentary elections in 2010. This majority enabled Fidesz to introduce a new constitution as the ruling party.

The civic circles no longer exist as such today, but there are indeed organisations that claim to be their heir, such as the Civil Union Forum (CÖF - Civil Összefogás Fórum) (Greskovits 2020: 262-263). Critics argue that CÖF is a government-based organisation and, similarly, those organisations which are connected to it. One of these is the Civil Union Public Benefit Foundation (CÖKA - Civil Összefogás Közhasznú Alapítvány). ${ }^{4}$ CÖKA claims to be non-profit and to represent ethnic Hungarians in neighbouring countries while, on its own website, CÖF claims to be solely financed by Hungarian resources and to represent Hungarian interests. These successor organisations to the civic circles still organise activities whose aims lie firmly within their ancestors' spirit. CÖKA, for example, is the organiser of the so-called 'peace marches' (békemenet) which have taken place since 2012 and which are organised mostly prior to parliamentary elections, such as in 2018, to demonstrate public support for Fidesz (Greskovits 2020: 263). ${ }^{5}$ Certainly, with the help of the civic circles, Fidesz was able to grow and expand its influence nationwide within the political right, which helps to explain the high voting results since 2010 in national parlia-

3 Translated by the author. Quote originally runs: 'Együtt fejlesztettük ki azt a képességet 2002 után, hogy egyszerre álljunk ki a visszatért vallásellenes, nemzetellenes és családellenes politikai vezetéssel szemben, és egyszerre szolgáljuk közben a hazánkat.'.

4 For further information: https://civilosszefogas.hu/en/.

5 See also: https://hvg.hu/itthon/20130425_Tenyleg_Fideszalapitvany_penzeli_a_bekem (accessed 11 September 2021). 
mentary elections but also in the elections which have been held at municipality level.

\section{Legislation on civil society organisations after 2010}

The divide between national supported organisations and those supported from abroad had its roots before the elections of 2010. In the period after Fidesz was returned to power, however, the new government introduced several pieces of legislation up to 2021 that has entirely changed the legal possibilities for civil society groups in Hungary.

The most notable of these is the so-called 'transparency law' concerning NGOs that received financial support from foreign sources, which was introduced in 2017. This law was initiated after the ongoing public debate about the finances of NGOs funded from abroad started in earnest in 2014. This debate emerged as a result of the so-called EEA/Norway grants, funded by Norway, Iceland and Liechtenstein ${ }^{6}$ to support projects in the economy, civil participation, the energy sector and others in fifteen different countries, including Hungary.

This article returns to the origins and nature of this public debate in a later subsection. However, the control and, if necessary, quieting of foreign influence was essentially the starting point for the transparency law which required the registration of organisations receiving more than HUF 7.2 million (then approximately $€ 24,000$ ) in foreign funding annually. The label of 'organisation receiving support from abroad' would also have to be put on publications, websites and press releases (Venice Commission 2017). The government explained the law's purpose in the context of ensuring the transparency of civil society organisations although, not least following the highly critical report of the European Parliament's Committee on Civil Liberties, Justice and Home Affairs (known as the Sargentini report, after its rapporteur) (European Parliament 2018) this was no longer a valid defence. Furthermore, NGOs already publish annual financial reports which are open access via the internet and therefore clearly transparent.

The European Commission initiated infringement proceedings against Hungary on the grounds that the law violated the free movement of capital within the EU and discriminated against organisations receiving funding from abroad (European Commission 2017): those receiving funding from within Hungary were not required to register, regardless of their amount of funding. After the government ignored the proceedings, the European Court of Justice ruled in June 2020 that the law was discriminatory against civil society organisations receiving funding from abroad, violated the rules on freedom of capital and limited the freedom of association of certain organisations, obliging the government to amend the law accordingly. However, the government did so only in February 2021, after further infringement proceedings had been initiated, with a law which was eventually adopted in June 2021.

The amended law now requires the registration of all civil society organisations that receive annual funding of more than HUF 20 million in annual funding (c. $€ 57,000$ at the time of the adoption of the amendment), regardless of funding source 
(Hungarian Prime Minister's Office 2021). Állami Számvevöszék (the National State Audit Office) now has the responsibility of reporting on an annual basis on registered organisations although this is inevitably problematic since this organisation - a state body - is responsible for the control of public funding which the NGOs concerned are not necessarily receiving, for example when they receive funding from abroad. Furthermore, the annual total funding of HUF 20 million, set as the limit of being free of the requirement of registration, targets organisations that are big in size and scope. In addition, the criteria under which such reviews will be produced have not as yet been determined; this will be done by another law which is yet to be published. This further widens the scope of action for the Hungarian government.

\section{New law on university foundations part of a change in the landscape of public life}

In 2021 the Hungarian parliament adopted a new law on universities converting them into foundations which will be given assets, real estate and shares in large companies. Eleven Hungarian universities are affected by this law and will no longer be state-owned (Schlagwein 2021). Critics of Orbán say that the law is designed to facilitate the retention of Fidesz's grip on power in public life in view of its potential defeat in next year's parliamentary elections, thereby implementing mitigations against such a loss. Firstly, the new foundation law can only be changed by a twothirds majority in parliament, which might be very difficult to attain for future governments. Secondly, the supervisory boards of the university foundations will be filled with like-minded people since Orbán explained in a radio interview in April 2021 that the trustees of the new foundations should be people who think in national rather than globalist terms:

Universities are national institutions, so they're the custodians of national sovereignty, national self-knowledge and consciousness, national learning and national culture. And we don't want them to become globalist institutions of some kind that have lost their national character. Of course they'll have to fit into the international environment, they'll have to compete there; but they'll have to compete as Hungarian universities. And by definition, when we set up these foundations and seek trustees, we'll be selecting people... who have this national approach. And that's why I can't wholeheartedly nominate an internationalist, globalist-minded person for such a board of trustees. (Radio Kossuth 2021)

The eleven universities and a majority of 70 per cent of Hungarian students will experience the same restructuring as SZFE (the University of Theatre and Film Arts) in Budapest, which was converted into a foundation in 2020. According to Orbán's interview, this university is such a good example of the new system that other universities 'announced a desire for the same restructuring' (Radio Kossuth 2021).

It is not possible currently to determine whether the universities voted for the restructuring themselves or whether this is indeed a politically motivated step towards achieving long-lasting power for the political right in Hungary; how the university foundations turn out in practice to work and act is a question for the future. The impression gained from this, however, is that the Hungarian government is trying to effect a long-term aspect to its rule, even if it is no longer in government, by dominating political cooperation with institutions which are significant in public life. It has 
already been determined that the minister of justice, Judit Várga, and the minister of foreign affairs, Péter Szijjárto, will be members of such boards (Schlagwein 2021).

Politico concluded from its surveys of national election voting intentions (Politico 2021) that the opposition bloc - consisting of the Socialist Party MSZP, the Green Party LMP, the left-liberal Democratic Coalition, Dialog, centrist newcomer Momentum and the formerly extremist right-wing Jobbik (Inotai 2021) - is currently standing on a par with Fidesz. Polls from earlier in the year show that there is an urbanrural divide in Hungary with the united opposition leading the polls in Budapest and some other larger cities while Fidesz support remains strong in rural areas (Inotai 2021). The main concern of Hungarians now is rising living costs rather than corruption or migration and this, to some extent, explains why people are dissatisfied with the current government. The question that remains is whether the rainbow opposition coalition of left, centre and right-wing parties would bring about better policies for Hungary in the event of an election victory. This question can be answered only in part by the larger cities, such as Budapest, where in 2019 the united opposition won the election and has been governing since but only with limited scope as the priority is to survive against government measures such as the removal of tax revenues and other financial resources. The most important issue ahead of the elections is whether or not the voters continue to support Orbán or not, with the ideological differences among the opposition having become less pronounced (Đorđević 2021). Nevertheless, the election is likely to be decided in the rural parts of the country.

Not only in the university foundations but also in other parts of public life will Fidesz-loyal politicians or appointees be in power in any post-Fidesz governing scenario: among others, the president of the Supreme Court has just been elected for a nine-year term while the governor of the central bank will be in post until 2025 (Inotai 2021). In addition, their successors - as with many of the country's laws - will have to be appointed by a two-thirds supermajority: a high barrier for future governments. The new law on university foundations is just one part of the political scene which highlights the ambitions of the current Hungarian government to ensure a long-lasting power base for right-wing politics in the country, as well as a leading role for the current prime minister even after any possible electoral defeat.

\section{Public debate about the foreign funding of NGOs and other organisations}

To understand the public debate about the role of foreign-funded civil society organisations in Hungary, it is important to explore the details of the dispute between the Hungarian and Norwegian governments on financial support for NGOs, referenced earlier on.

The dispute started in 2014 when the Hungarian government put responsibility for the management of the EEA/Norway grants into the hands of an enterprise owned by the government but without consulting the donor countries about this step. Subsequently the payments were suspended. The dispute about the funding was particularly heated because it also affected the civil society part of the grants. This fund differs from the remaining grants because it is not the governments that are responsible for the distribution of the funding but, instead, civil society organisations themselves. In Hungary there was a consortium of four organisations responsible - including, 
inter alia, the Hungarian Environmental Partnership Foundation Ökotárs. In the Memorandum of Understanding set out for the programme period, which extended from 2009 up until 2014, the donors and Hungary had agreed that the donor countries would determine the Programme Operator for the civil society grants in consultation with the National Focal Point in Hungary (EEA/Norway Grants 2011: Annex B 3(D)).

After the EEA/Norway grants had been suspended, a list of thirteen organisations receiving financial support from the civil society funds was published. This list included different organisations, for example those engaged in human or minority rights, gender equality and the rights of sexual minorities (LGBTIQ), but also groups involved in topics of anti-corruption, transparency, rule of law and Roma issues (Norwegian Helsinki Committee 2016: 3). Not only was the list published but the Hungarian government also accused these organisations of embezzlement and mismanagement of the grants which culminated in an investigation led by Kormányzati Ellenórzési Hivatal (KEHI), the government control office (Norwegian Helsinki Committee 2016: 3). Subsequently in May 2014 KEHI ordered an audit of the CSOs belonging to the consortium as well as 55 other organisations receiving funding from the EEA/Norway grants. KEHI usually audits public funding and its recipients and is therefore not eligible to audit CSOs as these do not receive public funding. Furthermore KEHI's independence has been put into question since its president can be appointed or dismissed by the prime minister (Amnesty International 2015: 9). The audit included police raids on the consortium but eventually, in October 2015, the Hungarian authorities conceded that the affected organisations were operating lawfully (Norwegian Helsinki Committee 2016: 3-4).

By the end of the year, the dispute had been resolved at government level with the Norwegian government claiming that the Hungarian government had accepted all its conditions and would refrain from getting involved with the administration of the funds and from harassing civil society organisations. However, the Hungarian government then issued a press release expressing further concerns about the Ökotárs foundation: ongoing allegations which damaged it and its public reputation in the long term.

Under new agreements covering the 2014-2021 period, $€ 214.6$ million was to be allocated by the donors to Hungary. The memoranda of understanding included details of the civil society programme which specifically regulated that organisations receiving support from the funds should be excluded from the scope of Hungarian laws concerning the immigration tax and the transparency law (EEA/Norway Grants 2020). The aim behind this was to ensure that the organisations receiving support could operate freely instead of fearing government interference in their work. The two sides also agreed that an independent fund operator for the civil society funds would be announced and accepted by both the donors and Hungary by 21 July 2021. However, no agreement could be reached. As a result, payments under the EEA/ Norway grants were again stopped as were all programmes, including the civil society programme, projects in the energy and economy sectors and projects with reference to young people and long-term engagement in under-served areas outside the metropolitan ones (EEA/Norway Grants 2021a). 
The Hungarian government has used all its possibilities to prevent the further commitment of civil society, which could threaten the ruling party, by blocking the appointment of the fund operator. The organisations involved have lost very important support and are not able to continue their projects throughout this period. In addition Viktor Orbán has reinforced his statements seeking to preventing foreign influence in Hungarian politics that is not controlled by the government or similar body, to which he referred in his 2014 speech at the 25th Bálványos Summer Free University in Băile Tuşnad, Romania (Hungarian Prime Minister's Office 2014).

\section{Public billboard campaigns initiated by the Hungarian government}

Besides the legislation concerning civil society organisations and their scope of action, there have been billboard campaigns organised by the Hungarian government which have been accompanying the important so-called 'national consultations' which have been held since the peak of the refugee crisis in summer 2015. These campaigns used slogans such as 'If you come to Hungary, don't take the jobs of Hungarians!' or 'If you come to Hungary, you have to keep our laws' (Thorpe 2015).

In these campaigns both the face of George Soros and the then president of the EU Commission, Jean-Claude Juncker, were put on the billboards, always tying up with organisations supported by the Soros Foundation or by other EU member countries. Furthermore, these billboards were in the Hungarian language, raising concerns that it was not refugees that were the targets of these media campaigns but Hungarian citizens as a means of influencing their views on the refugee situation. Public consciousness here was fuelled by an article written in 2015 by George Soros who explained that the European Union might have to take in one million refugees annually in response to the war in Syria (Soros 2015), later (when circumstances had changed) lowering this figure to 300000 (Soros 2016). The atmosphere was a charged one in which the heat was being turned up considerably on the conspiracy against Soros and his financial contributions to civil society organisations; and so the public rhetoric changed dramatically.

Two years later, further public national consultations were held in which Hungarian citizens could again express their opinions on migration and the refugee situation. In the course of these consultations billboards were once more put up advertising: 'National Consultation about the Soros Plan. Speak up!'. In question 5 of this consultation the Hungarian Helsinki Committee was identified and accused of fighting for more lenient punishments for migrants who had committed crimes, something which was said to have been orchestrated by Soros and which later led to a lawsuit filed by that organisation (Hungarian Helsinki Committee 2017). Amnesty International was named in the same consultation as fighting on behalf of a refugee imprisoned for throwing stones at police on the border; while the Hungarian government also consulted (in question 2) on the removal of border fences which, it said, was an important goal of the Soros Plan but which would open the borders to undocumented immigrants. Even though the Hungarian Helsinki Committee eventually won its lawsuit (Hungarian Helsinki Committee 2019) its public reputation had been damaged by the government's accusations and billboards. 
Even during the Covid-19 pandemic there have again been billboards in Hungary showing statements like: 'Is George Soros about to attack again?', 'Are you outraged about illegal immigration?' and 'Does Brussels drive you mad?' These billboards accompanied a further national consultation, held in July and August 2021 about life after the pandemic (Government of Hungary 2021). This contained not only questions about the virus and the state but also included references to Soros by name, again accusing him and the organisations supported by him of support for illegal migration. That the Hungarian government still uses such hostile rhetorical formulations in influencing the broader public and strengthening the narrative on migration and otherness is concerning. Public opinion is being orchestrated against migration and the organisations allegedly supporting this, by way of reference to the traditions and values of Hungarian society, and the result is little but a defamation of such organisations and their work.

The emergence of the civic circles, the legislation on civil society organisations and on the reformed structure for higher education show that the Orbán governments and Fidesz are eager to change the scope for independent organisations by addressing their funding. In addition their loyalty to Hungary is openly being questioned and the divide between national- and international-supported civil society is widened. Not only are such independent organisations being defamed by these questionnaires and billboard campaigns, facilitating a hostile attitude towards them, but this is problematic in terms of Hungary's democratic position since these organisations also represent parts of society which do not follow right-wing political views.

\section{Hungary's influence in neighbouring countries}

Besides Orbán's treatment and approach to the architecture of civil society in Hungary, he is also intervening via Fidesz in countries throughout the region both directly and indirectly. Hungarian influence is targeting long-term power structures in its neighbouring countries, as revealed by a three-part investigation by Balkan Insight in Slovenia, Serbia and Romania, in each of which there is an increase of Hungarian influence over media, culture and funds being facilitated by Orbán (KellerAlant 2020). His engagement in the countries of the region with substantial Hungarian minorities - the result of the 1920 Treaty of Trianon - is yet another sign of his attempt to coordinate a region of 'illiberal democracies' which demonstrate conservative Christian values and which are in opposition to migration to Europe (Terenzani et al. 2020).

In this context Fidesz and its leader have become involved in the Slovakian civil society landscape, given that there are ethnic Hungarians living in Slovakia, while the Slovenian government, which is depicted as an ally of the Hungarian government, has started to develop certain behaviour towards its civil society organisations as its media campaigns and populist consultations demonstrate. This contributes to a consolidation of nationalist-inspired power bases and the mobilisation of such principles in both Slovakia and Slovenia. Orbán's obsession with raising his prestige and influence within the region thus stands out. In the following sub-sections, the civil society situations in both Slovenia and Slovakia will be presented and the character of the Hungarian influence analysed. 


\section{Slovenia's situation of civil society organisations - similarities with the Hungarian case}

After spring 2020, when Slovenian prime minister Janez Janša came to power, supported by his Slovenian Democratic Party (SDS) and other coalition parties, they adopted the Hungarian concept of handling civil society organisations like public enemies. Since then the danger of a new authoritarian leadership, as in Hungary, has been continuing to increase - something which is a matter of regret to University of Ljubljana sociologist Rudi Rizman:

It is regrettable that Slovenia, once celebrated as an international success story, has now become a victim of the two authoritarian politicians, Janša and Orbán. ${ }^{7}$ (Verseck 2020)

Nevertheless, according to the government's own website, but quoting an independent source (Civicus Monitor):

Slovenia is one of the few open societies in which civil society is not limited by the state. ${ }^{8}$

Civil society has a long tradition in Slovenia as between the two world wars there were around 8000 organisations which were active although, during the period of state socialism, the number of organisations inevitably dropped because of the state's monopoly of the sector. After the 1970s, there was a period of decentralisation up until the 1990s when a number of new associations were established. This culminated in legislation on CSOs and engagement (Rakar et al. 2011: 22-24).

Today, however, in contrast to the explanation on the government website, Civicus Monitor officially designates the picture in Slovenia as 'narrowed', since the situation facing civil society in Slovenia has deteriorated in the period since November 2020 as a result of the government measures and hostile rhetoric which have targeted the sphere (Civicus Monitor 2020). This goes as far as eighteen organisations being threatened with eviction from the building in which they had operated since the mid-1990s but which belonged to the Slovenian Culture Ministry. The building is to be renovated before, in the future, housing the National History Museum of Slovenia. The organisations have not, however, been provided with alternative accommodation and so they assume that the eviction is rather to silence them as they had also been critical of the government. They are portrayed in the media which belongs to SDS as well as by Janša himself as 'privileged' and as 'parasites' (Civicus 2021), a difficult situation for the organisations concerned which are not only being forced out of their offices but also defamed.

The changed behaviour of the government towards civil society was seen soon after its accession to office in March 2020. It announced an intention to annul several contracts with CSOs some of which were active in fighting for the equality of mi-

7 Translated by the author. Quote originally runs: 'Es ist bedauernswert, dass das einst international als Erfolgsgeschichte gefeierte Slowenien nun ein Opfer der beiden autoritären Politiker Janša und Orbán geworden ist'.

8 See: https://www.gov.si/en/policies/state-and-society/civil-society/. The page is dated as last edited on 19 October 2020. 
grant children in schools. When the affected organisations refused to sign, the government withheld their funding. The amount involved may only have been small but, for such organisations and their projects, it is vital.

Furthermore, the Slovenian government has used Covid-19 emergency measures to obstruct the participation in public life of civil society organisations, targeting environmental groups and departing from its previously high standards of civil society participation (Civicus 2021). According to the Environmental Protection Act in Slovenia non-governmental organisations holding status as 'public interest' are allowed to take part in decision-making processes on environmental matters such as the approval procedures for construction permits. In compliance with the Covid-19 emergency laws, environmental organisations now have to meet stricter criteria in order to be involved in these procedures. These criteria specify a minimum of 50 active members in the case of associations; a minimum of three fully employed staff with university education in the field in the case of environmental institutes; and lastly, if the organisations concerned are constituted as institutions or foundations, they must have assets of at least $€ 10000 .{ }^{9}$ These changes to the law on the participation of environmental organisations thus make it easier and faster to issue construction permits - which may speed up infrastructure investments during the recovery of the economy - but which also turn out to be harder to meet for non-governmental organisations.

During the Covid-19 pandemic, in December 2020, the Slovenian government tried, albeit unsuccessfully, to introduce an amendment to abolish the state fund for non-governmental organisations. By way of important background, the Strategy for Developing Non-Governmental Organisations and Volunteering until 2023 had been intended to improve the level of cooperation between NGOs and the state, strengthen the integration and efficiency of the NGOs and develop high-quality volunteering across all segments of the society, aims which were to be met by state funding for organisations. The Strategy had determined that paid jobs and the availability of additional training would professionalise the staff of organisations and thus contribute to sustainable employment and strengthened civil society development. This is important because, as data show, no less than 90 per cent of NGOs in Slovenia work without employees (Štremfelj et al. 2020: 1). The Strategy included a fund on which each citizen could spend 0.5 per cent of income tax on certain public interest organisations; if citizens did not declare an organisation, the unspent allocation would be transferred to a central fund to which organisations could apply for funding (Civicus 2021). This fund was introduced by the previous government and resulted from long negotiations with the national civil society umbrella organisation in Slovenia.

Despite the Strategy's aim of strengthening civil society, the opposite has actually taken place since the new government entered office with its cuts to public funding for organisations, referred to by SDS in its election campaign. The government's decisions on CSOs and their funding might thus come as no surprise but they do represent a step backwards in the treatment of such organisations by the Slovenian state.

9 Article 100.f of the Act Determining the Intervention Measures to Contain the COVID-19 Epidemic and Mitigate its Consequences for Citizens and the Economy (ZIUZEOP) 2020. 
The European Parliament's Policy Department for Citizens' Rights and Constitutional Affairs cites a report from the Civil Liberties Union for Europe that:

NGOs and other informal groups critical of the political situation in the country are often subject to smear campaigns. These target for example NGOs working in the fields of environment protection, culture, human rights and non-discrimination, and LGBTI rights... Such campaigns include depicting NGOs as parasites, spreading misinformation about their operations and financing, including deliberately creating misconceptions about the organisations' functioning and strength; publishing hostile and insulting articles about organisations, their founders and staff in attempts to compromise their public image and legitimacy. (European Parliament 2021: 29)

The report went on to attribute such measures to media outlets close to the current government. In addition, it also referenced questionnaires being sent to households which included questions about civil society organisations and their funding similar to those used by the Hungarian government in its so-called 'national consultations' mentioned above.

Civil society organisations in Slovenia have not yet been silenced; they are trying to defend themselves against the attacks of government officials for example by carrying out advocacy work with the smaller coalition parties of the SDS to influence votes in parliament. However, the government is finding other ways to exert influence on organisations which are critical of it by submitting bills to parliament restricting their scope of activity. The situation facing environmental groups is an example, showing very difficult conditions which exclude such organisations from key relevant consultative procedures (European Parliament 2021).

The treatment of certain civil society organisations and Janša's aggressive rhetoric reminds us of the anti-CSO rhetoric and smear campaigns against critical organisations and their funders which have been developed in Hungary. Besides, the Hungarian and Slovenian prime ministers attend each other's election rallies, share similar political values and are described as political allies (Civicus 2021). By identifying similar public debates in Slovenia concerning the engagement of civil society organisations in politics, one can consider the Hungarian example as constituting a role model for Janša and his SDS government. The influence of the Hungarian government and Fidesz is therefore not direct but, has been shown, indirect since the behaviour of the Slovenian prime minister closely resembles that of Viktor Orbán in his country.

\section{Civil society in Slovakia and Hungarian ambitions}

The situation of civil society and, accordingly, Hungary's influence in Slovakia is different in comparison with the Slovenian model. The state of civil society organisations in Slovakia is partly affected by registration requirements or smear campaigns implemented by politicians. The Hungarian government is also exerting direct influence on the civil society landscape of Slovakia on the grounds of the existence there of a large Hungarian minority in respect of which it sees its engagement as indispensable to the defence of Hungarian interests. 
The current position of Slovak civil society is slightly different than in Slovenia and Hungary. At national level, organisations are part of the so-called Governmental Council for NGOs while civil society is important to Slovak democracy, as Martin Giertl, Plenipotentiary of the Government of Slovakia for Civil Society since 2014, points out in an article in the Slovak Spectator (Slovak Spectator 2020). The office of the Plenipotentiary was introduced on the one hand to facilitate cooperation and communication between organisations and government institutions; while, on the other, it should help initiate policy and legislative changes related to the development of civil society and the participation of organisations in decision-making. The organisational status of civil society in Slovakia is rather weak and most such organisations are small and volunteer-based, acting at local and community level (Svidroňová 2020: 47).

Nevertheless, there have been attempts by politicians and political parties to change the scope of activities and the regulations under which civil society operates. The far-right People's Party Our Slovakia (LSNS), for example, has tried several times to introduce the label of 'foreign agents' for organisations in the country which accept monies from abroad, similar to Hungary's 2017 transparency law on CSOs. None of the attempts have been successful but they are indeed a sign of the hostility towards organisations from civil society in Slovakia, also demonstrated by the former prime minister of the country, Robert Fico, who chairs the social democratic party Smer, after the protests which followed the murder of Ján Kuciak and Martina Kušnírová in February 2018 (Slovak Spectator 2020). The journalist and his fiancée were killed after an investigation which Kuciak was undertaking into the ties between Slovakia's top politicians and the Italian mafia. The deaths led to a mass protest in Bratislava demanding the resignation of Fico and a political crisis which resulted in Fico's resignation the following month. During the crisis, Fico accused Andrej Kiska, Slovak President, an old political rival, of working with George Soros to destabilise the government (Politico 2018), an accusation which stems from a meeting held in September 2017 when the two met on the issue of the better integration of the Roma community in Slovakia (Slovak Spectator 2018). This shows a similarity to the Hungarian approach to Soros and his role in the region via the development of smear campaigns.

In further comparison to the Hungarian civil society landscape, there is also a law in Slovakia requiring the registration of NGOs and other civil society organisations. This registration is mandatory when organisations apply for public funding, including state funding via the 2 per cent finance accessible from income tax receipts. The reason for this law, according to the Slovakian government, is the transparency of all civil society organisations. In contrast, critics raise concerns that the registration requirements are actually too detailed in terms of the country's privacy law (e.g. the requirement for dates of birth) and is thus too extensive. Besides there is already a reporting requirement for all organisations receiving annual funding of more than $€ 200000$ under which such organisations have to submit an audited financial report displaying their sources of funding which must be made publicly available. The impression arises that the registration law might, on the one hand, be for transparency reasons but, on the other, to have such detailed information about who is engaged in 
which organisation, against the background of the public debate which already exists about Soros and his engagement in the region, also leaves room for speculation as to whether this is the real reason behind the registration requirement.

The similarities in the civil society legislation is not the only reflection of Hungarian influence in the Slovakian civil society landscape: this is also overtly present in terms of the investment which the Hungarian government and Fidesz are actively making in the projects of ethnic Hungarians and communities in the country. On the list are schools, cultural centres, small businesses and football stadiums. In this regard, the city of Komarno received millions of Euros for the reconstruction of a football stadium. Members of the Hungarian minority are divided about these activities and others: some are open to Hungarian engagement while others see Fidesz's involvement as the most critical aspect because of its illiberal tone (Terenzani et al. 2020).

According to reports by the website HungarianMoney.eu, which is composed of investigative journalists and online media throughout the countries which neighbour Hungary, the investments of the Hungarian government into organisations and the cultural development of ethnic Hungarian minorities in these countries is not new, but has been increasing since 2011. Since then, financial support for Hungarian minorities in neighbouring countries has been declared even in the constitution of Hungary, where it is written that Hungary shall provide support for Hungarians living beyond its borders. ${ }^{10}$ Grants from the state in Slovakia culminate in the allocation by now of more than $€ 144$ million to the Gábor Bethlen Foundation for:

cultural organizations, Reformed Christian Church, for the reconstructions of schools and kindergartens, media, but Budapest [has] supported also important symbols - Slovak Hungarian football club 'Ferencváros of Felvidék' FC DAC Dunajská Streda and its football academy. ${ }^{11}$

In addition there has also been a transfer of money to a minority NGO in Slovakia, Fönix, which was allegedly funding the political campaign of the SMK party which represents Hungarians in the country. The Fönix association has no website where it could provide information about its projects or justify them. Furthermore, according to HungarianMoney, the association's payroll extended to József Berényi, the former chair of SMK and its current vice-chair. This whole case is critical as it is prohibited by law in Slovakia to use foreign money for political campaigning.

The direct influence of the Hungarian government in Slovakia can be attributed to the needs of Fidesz for the votes of ethnic Hungarians living abroad. As Politico's polls in Hungary have shown (see above), it is possible that Fidesz could see electoral defeat in the upcoming parliamentary elections in spring 2022. The dual citizenship required to allow ethnic Hungarians living abroad to vote in Hungarian elections has been the subject of conflict between the Hungarian and the Slovak governments. At the same time, however, the 'brain drain' from Hungary requires it to fill a hole in

10 Article D.

11 For detailed information: http://hungarianmoney.eu/icjk-hungarian-money-for-slovak-south /. 
its labour market in which ethnic Hungarians from neighbouring countries may well play an important role. In addition, this engagement of the Hungarian government is in line with Orbán's views of the need for countries which share Christian values to stand against non-European immigration (Terenzani et al. 2020). This is also highlighted by the defamation of Soros and his financial contributions to Slovakian civil society organisations which shows clear parallels to Hungarian proceedings in the civil society sector.

\section{Conclusion}

This article has discussed the relationship between the right-wing Hungarian government and civil society organisations and its repercussions for other countries in south-eastern Europe.

The purpose of Viktor Orbán's anti-civil society campaigns is simple: Fidesz, he argues, lost power in 2002 because conservative forces in Hungary were not rooted in society and, accordingly, such forces need now to become better entrenched. After the comeback of Fidesz in 2010, the agenda was to support the political right and right-wing power structures and to secure election victories in Hungary. In fear of electoral defeat in the upcoming national parliamentary elections, Fidesz is changing the university landscape to secure right-wing hegemony, independent of the results of the elections. At the same time, since 2017, civil society organisations have faced legislation that has limited their scope of activities and public smear campaigns designed to force them to change their scope of operations or stop their activities completely. The Hungarian government cooperates with organisations that openly share Christian and conservative values; other organisations, however, are confronted with narrowing possibilities and defamation. In the process, there is legislation on the financing of organisations which is designed to reject civil society engagement in public policy-making, even though this is in line with European and democratic values. Indeed, there is structural discrimination against civil society organisations that are financed from abroad. This illustrates the aggressive behaviour of the government not only against such organisations and their donors but which is also contrary to democratic and European values.

Furthermore, the treatment of civil society groups critical to the government fosters the thesis of the efforts of Orbán and Fidesz to build long-lasting right-wing power structures across the region. The role of neighbouring countries such as Slovenia or Slovakia, and Hungary's influence on them, is crucial in building these longterm right-wing power structures. These countries are already walking on similar paths.

In Slovenia, where such a path is relatively new, the treatment of civil society organisations critical to the government shows similarities to the Hungarian case. This appears in smear campaigns being conducted against CSOs as well as in the public questionnaires being circulated by the government concerning the role and activities of these organisations, or their threatened eviction from their accommodation. Additionally Covid-19 emergency legislation has been used to put limits on the participation of NGOs, especially those concerned with the environment, in the process of decision-making. Furthermore, the Slovenian government limited state funding for or- 
ganisations soon after its inauguration in spring 2020 while contracts with organisations have been annulled, or funding withdrawn, from joint projects between the government and CSOs.

Hungary's engagement in the civil society landscape of Slovakia cannot solely be explained by Orbán seeking to take care of ethnic Hungarians living there. The reason why the Hungarian government has ambitions to exert influence in the country can, on the one hand, be traced back to the building of long-lasting power structures of illiberal countries in the region, favouring national and right-wing interests. On the other, Hungary has a demographic problem and faces a possible electoral defeat according to the polls which is why the government is active in neighbouring countries to secure its power structures on top of seeking to win the election.

This engagement and the related influence of the Hungarian government is not openly political but, as the examples show, its support for neighbouring countries is particularly diverse. With this in mind, further research needs to be done to bottom out the depths of that diversity, link the power structures that are being created and include other countries in the region.

\section{References}

Amnesty International (2015) 'Their backs to the wall - Civil society under pressure in Hungary' London: Amnesty International Publications, accessed 10 November 2021 at: https://www.amnesty.org/en/wp-content/uploads/2021/05/EUR2700012015ENGLISH.pdf.

CEU Democracy Institute (2019) 'Report: Establishment of KESMA Exacerbates the Overall Risk to Media Pluralism in Hungary' accessed 14 October 2021 at: https: //cmds.ceu.edu/article/2019-08-08/report-establishment-kesma-exacerbates-overa 11-risk-media-pluralism-hungary.

Civicus (2021) 'Slovenia: "The government has taken advantage of the pandemic to restrict protest"” accessed 6 November 2021 at: https://www.civicus.org/index.ph $\mathrm{p} /$ media-resources/news/interviews/4931-slovenia-the-government-has-taken-adv antage-of-the-pandemic-to-restrict-protest.

Civicus Monitor (2020) 'Janša's government threatens to evict 18 CSOs and continues to attack the media' accessed 19 October 2021 at: https://monitor.civicus.org/ updates/2020/11/16/jansas-government-threatens-evict-18-csos-and-continues-att ack-media/.

Civicus Monitor (2021) 'Government attempts to muzzle independent media by controversial anti-TVN law' accessed 19 October 2021 at: https://monitor.civicus.or g/updates/2021/09/02/government-attempts-muzzle-independent-media-controve rsial-anti-tvn-law/.

Diamond, Larry (1994) 'Rethinking civil society: toward democratic consolidation' Journal of Democracy 5(3): 4-17.

Đorđević, Nikola (2021) 'Does Hungary's united opposition finally have a shot at toppling Viktor Orbán?' Emerging Europe 6 October, accessed 10 November 
2021 at: https:/emerging-europe.com/news/does-hungarys-united-opposition-fin ally-have-a-shot-at-toppling-viktor-orban/.

EEA/Norway Grants (2011) 'Memorandum of understanding on the implementation of the EEA financial mechanism 2009-2014' accessed 11 October 2021 at: https:/ /eeagrants.org/sites/default/files/resources/MoU\%2BEEA-Hungary\%2B2009-20 14.pdf/.

EEA/Norway Grants (2014) 'Suspension of EEA and Norway Grants to Hungary' accessed 11 October 2021 at: https://eeagrants.org/news/suspension-of-eea-and-n orway-grants-to-hungary.

EEA/Norway Grants (2020) 'New cooperation agreements with Hungary' accessed 12 October 2021 at: https://eeagrants.org/news/new-cooperation-agreements-hun gary.

EEA/Norway Grants (2021a) 'Public consultation on new civil society programme in Hungary’ accessed 12 October 2021 at: https://eeagrants.org/news/public-consultation-new-civil-society-programme-hungary.

EEA/Norway Grants (2021b) 'No agreement reached on funding for Hungary' 23 July, accessed 10 November 2021 at: https://eeagrants.org/news/no-agreement-reac hed-funding-hungary.

European Commission (2017) 'European Commission steps up infringement against Hungary on NGO Law' accessed 10 November 2021 at: https://ec.europa.eu/com mission/presscorner/detail/en/IP_17_3663.

European Parliament (2018) Draft report on a proposal calling on the Council to determine, pursuant to Article 7(1) of the Treaty on European Union, the existence of a clear risk of a serious breach by Hungary of the values on which the Union is founded (2017/2131(INL)) 11 April, accessed 10 November 2021 at: https://w ww.europarl.europa.eu/resources/library/media/20180411RES01553/20180411R ES01553.pdf.

European Parliament (2021) 'The situation of democracy, the rule of law and fundamental rights in Slovenia', Policy Department for Citizens' Rights and Constitutional Affairs: Brussels, accessed 10 November 2021 at: https://www.europarl.eu ropa.eu/cmsdata/231906/SLOVENIA\%20IDA\%20DRFMG.update.pdf.

Government of Hungary (2021) 'Nemzeti konzultáció - A kormány közzétette a most induló nemzeti konzultáció kérdéseit' ('The government has published questions on the national consultation, which is now underway'), accessed 11 August 2021 at: https://koronavirus.gov.hu/cikkek/nemzeti-konzultacio-kormany-kozzetette-most-indulo-nemzeti-konzultacio-kerdeseit.

Greskovits, Bela (2020) 'Rebuilding the Hungarian right through conquering civil society: the Civic Circles Movement' East European Politics 36(2): 247-266.

Hungarian Helsinki Committee (2017) 'The Helsinki Committee filed a lawsuit against the government for the "National Consultation"" accessed 21 October 
2021 at: https:/helsinki.hu/en/the-helsinki-committee-filed-a-lawsuit-against-thegovernment-for-the-national-consultation/.

Hungarian Helsinki Committee (2019) 'Hungarian Helsinki Committee wins lawsuit against government at Supreme Court' 22 November, accessed 10 November 2021 at: https://helsinki.hu/en/hungarian-helsinki-committee-wins-lawsuit-agains t-government-at-supreme-court/.

Hungarian Prime Minister's Office (2014) 'Prime Minister Viktor Orbán's Speech at the 25th Bálványos Summer Free University and Student Camp', 30 July, accessed 10 November 2021 at: http://2010-2015.miniszterelnok.hu/in_english_arti cle/_prime_minister_viktor_orban_s_speech_at_the_25th_balvanyos_summer_fr ee_university_and_student_camp.

Hungarian Prime Minister's Office (2021) évi..... törvény a közélet befolyásolására alkalmas tevékenységet végző civil szervezetek átláthatóságáról és az ezzel összefüggő egyes törvények módosításáról [Act of .... 2021 on the transparency of non-governmental organizations active in the field of public life and amending certain related laws] accessed 11 October 2021 at: www.parlament.hu/irom41/15 991/15991.pdf?fbclid=IwAR0W2FxKrZH42Gd3DzdABKAWjz9Dt19Ppl6nFTwjeNoeqLyZE6TwIe5chic.

Inotai, Edit (2021) 'Governing, not winning, seen greater test for Hungary's united opposition' Balkan Insight 24 March, accessed 13 October 2021 at: https://balkaninsight.com/2021/03/24/governing-not-winning-seen-greater-test-for-hungarysunited-opposition/.

Keller-Alant, Akos (2020) 'Imitating Orbán: Hungary’s illiberal democracy goes beyond borders' Balkan Insight 30 January, accessed 10 November 2021 at: https:// balkaninsight.com/2020/01/30/imitating-orban-hungarys-illiberal-democracy-goe s-beyond-borders/.

Magyar Kurír (2017) 'Orbán Viktor előadása a Keresztény Értelmiségiek Szövetségének kongresszusán' ('Speech by Viktor Orbán at the congress of the Association of Christian Intellectuals') accessed 12 August 2021 at: https://www. magyarkurir.hu/hirek/orban-viktor-eloadasa-kereszteny-ertelmisegiek-szovetsegenek-kongresszusan.

Norwegian Helsinki Committee (2016) 'Hungary must provide space for civil society’ Policy Paper No. 1 2016, accessed 11 October 2021 at: www.nhc.no/content/ uploads/2018/08/NHC_PolicyPaper_1_2016_Hungaryspaceforcivilsociety.pdf.

Politico (2018) 'Slovak PM Robert Fico resigns' Politico 15 March, accessed 10 November at: https://www.politico.eu/article/robert-fico-resigns-slovakia-primeminister/.

Politico (2021) 'Hungary - National Parliament voting intention' accessed 11 August 2021 at: www.politico.eu/europe-poll-of-polls/hungary/.

Radio Kossuth (2021) 'Viktor Orbán's radio interview in "Good Morning Hungary" accessed 13 October 2021 at: https://miniszterelnok.hu/prime-minister-viktor-orb 
an-on-the-kossuth-radio-programme-good-morning-hungary-50/ (NB translation at this link supplied by Cabinet Office of the Prime Minister).

Rakar, Tatjana, Tomaž Deželan, Senka Vrbica, Zinka Kolarič, Mateja Nagode and Andreja Črnak-Meglič (2011) Civil society in Slovenia Official Gazette of the Republic of Slovenia, Ministry of Public Information, Social Protection Institute of the Republic of Slovenia and Legal Information Centre for NGOs - PIC, August.

Schlagwein, Felix (2021) 'Hungary's Viktor Orban seeks to control universities' accessed 13 October 2021 at: www.dw.com/en/hungarys-viktor-orban-seeks-to-con trol-universities/a-57444869.

Slovak Spectator (2018) 'Soros: I am not behind Kiska speech, nor behind protests' Slovak Spectator 6 Mar, accessed

Slovak Spectator (2020) 'Civil society seen as the best cure to safeguard democracy', 24 January, accessed 19 October 2021 at: https://spectator.sme.sk/c/22309594/civ il-society-seen-as-the-best-cure-to-safeguard-democracy.html.

Soros, George (2015) 'Rebuilding the asylum system' Project Syndicate 26 September, accessed 10 November 2021 at: https:/www.project-syndicate.org/commentary/rebuilding-refugee-asylum-system-by-george-soros-2015-09.

Soros George (2016) 'Saving refugees to save Europe' Project Syndicate 12 September, accessed 10 November 2021 at: https:/www.project-syndicate.org/commentary/comprehensive-european-refugee-plan-by-george-soros-2016-09.

Štremfelj, Livija, Jana Žnidaršič and Miha Marič (2020) 'Government-Funded Sustainable Development and Professionalisation of NGOs' Sustainability 12(18): $7363 \mathrm{https}: / /$ www.mdpi.com/2071-1050/12/18/7363/htm.

Svidroňová, Mária Murray (2020) 'Civil society in Slovakia: current state and challenges’ Problemy Polityki Spotecznej 50(3): 43-60.

Terenzani, Michaela, Nina Hrabovska Francelova and Radka Minarechova (2020) 'Slovak election to test Orbán's clout among ethnic Hungarians' Balkan Insight 12 February, accessed 19 October 2021 at: https://balkaninsight.com/2020/02/12/ slovak-election-to-test-orbans-clout-among-ethnic-hungarians/.

Thorpe, Nick (2015) 'Hungary's poster war on immigration' accessed 13 October 2021 at: www.bbc.com/news/world-europe-33091597.

Venice Commission (2017) Opinion on the draft law on the transparency of organisations receiving support from abroad adopted by the Venice Commission at its 111th plenary session (Venice, 16-17 June), accessed 10 November 2021 at: https://www.venice.coe.int/webforms/documents/default.aspx?pdffile=CDL-AD( 2017)015-e.

Verseck, Keno (2020) 'Slowenien wird orbánisiert' Der Spiegel 7 March 2020, accessed 8 November 2021 at: https://www.spiegel.de/ausland/slowenien-janez-jan sa-wird-neuer-regierungschef-a-c60826e6-887a-46c8-9923-c3d1a0e69f01. 
Melanie Hien is a PhD candidate at Universität Regensburg, Universitätsstraße 31, 93053 REGENSBURG; and a scholarship holder of the Hans-Böckler-Stiftung, Georg-Glock-Str. 18, 40474 DÜSSELDORF, Germany. e-mail: melaniehien@gmx .de.

\section{(c) (P) $९$ \\ (C) Melanie Hien}

